\title{
Erratum to: Universal Temporal Dependence of Survival Probability for Diffusing Particles in Multidimensional Media with Absorbing Traps in an Electric Field
}

\author{
V. E. Arkhincheev ${ }^{a, b, *}$ \\ ${ }^{a}$ Laboratory of Applied Physics, Advanced Institute of Materials Science, Ton Duc Thang University, \\ Ho Chi Minh City, 700000 Vietnam \\ ${ }^{b}$ Faculty of Applied Sciences, Ton Duc Thang University, Ho Chi Minh City, 700000 Vietnam \\ *e-mail: valeriy.arkhincheev@tdtu.edu.vn \\ Received March 19, 2020; revised March 19, 2020; accepted March 19, 2020
}

DOI: $10.1134 / \mathrm{S} 1063776120300019$

Two misprints have been made in the affiliation of the author:

- Advanced Institute of Material Science, should be read Advanced Institute of Materials Science.

- Faculty of Applied Science should be read Faculty of Applied Sciences.

The e-mail address valeriy.arkhincheev@tdtu.edu.v should be read valeriy.arkhincheev@tdtu.edu.vn.

The original article can be found online at

https://doi.org/10.1134/S1063776119120112 